\title{
MANAGEMENT AND MEMBERSHIP IN CANADIAN CO-OPERATIVES
}

\author{
DANIEL ISH*
}

\begin{abstract}
Certain basic principles distinguish a co-operative corporation from an ordinary business corporation. With these principles in mind, Mr. Ish critically examines the law with respect to the management and membership of Canadian co. operatives. While provincial statutes are compared and contrasted, the author places particular emphasis on the provisions of the Canada Co-operative Associations Act. More specifically, the article deals with the distribution of corporate control, the qualifications, appointments, duties and removal of directors, and the admission, termination and voting rights of the members of a cooperative.
\end{abstract}

\section{INTRODUCTION}

The co-operative corporation differs from the ordinary business corporation in many basic ways. Although both business forms have as their ultimate goal the economic advancement of their members or shareholders, the means by which this common goal is achieved differs substantially.

Shareholders in the ordinary business corporation usually purchase shares in the hope that the shares will increase in value. Such shareholders view the purchase as an investment which will reap a profit-there is a speculative element to the investment. On the other hand, co-operatives have often been characterized, in contradistinction to ordinary business corporations, as lacking the speculative or profit making element. Although this may be true, it is erroneous to speak of cooperatives as non-profit organizations. It is the goal of a co-operative to advance the economic welfare of its members through the economies of large scale production, marketing or purchasing. Members invest in cooperatives not to achieve a gain on their capital investment but to provide operating capital. If the co-operative is successful, its operation will result in an economic gain to its members manifested in lower priced goods, if one is dealing with a purchasing co-operative, or lower production costs, if one is dealing with a producer's co-operative, to give just two examples.

The aims of a co-operative have recently been stated as follows: ${ }^{1}$

... to socialize the interests of the members by eliminating or minimizing the role of the member qua investor and maximizing the role of the member qua patron, restricting the return on invested capital to a nominal rate, requiring that the surplus of the cooperative be distributed to the members according to their patronage rather than their investment and by substituting for the capitalist principle of 'one vote per share' the cooperative principle of 'one vote per member' regardless of the number of shares.

Three main areas thus surface which distinguish co-operatives from ordinary business corporations. They are:

(1) the role of investment capital;

(2) the distribution of surplus or profits;

(3) membership or shareholder voting rights.

These basic co-operative principles have become known as the Rochdale

- Of the College of Law, Univeraity of Saskatchewan, and of the Bar of the Province of Alberta.

' Report on Co-operatives by Select Committee on Company Law (Ont. 1971) 2, [hereinafter referred to as the "On. tario Report".] 
principles because of their expression in the founding documents of a small consumer's co-operative in 1844 in Rochdale, England. ${ }^{2}$ These principles are enshrined, to a greater or lesser extent, in Canadian cooperative legislation.

The following pages are limited to a consideration of the management and membership in Canadian co-operatives. The law is discussed and assessed in view of the basic co-operative principles. Because legislation plays such a large role, a detailed analysis is made of many of the statutory provisions. As with ordinary business corporations, each jurisdiction in Canada has a statute enabling incorporation of cooperatives. With the exception of Ontario and Manitoba, each jurisdiction has a separate Act pertaining to co-operatives. ${ }^{3}$ In the two excepted jurisdictions, special parts of the general companies acts have been devoted to co-operatives. ${ }^{4}$

The Canada Co-operative Associations Act ${ }^{5}$ was passed by the federal Parliament in 1970.6 Since it is the most recent attempt by any Canadian jurisdiction to revise co-operative law, the Canada Act is used as the legislative focal point. Provincial statutes, especially Ontario and Saskatchewan, are often discussed, usually by way of contrast or to better illustrate a point. Also many references are made to the common law and statutory provisions relating to the ordinary business corporation. Since co-operatives are merely a type of corporation, much of the law and learning which is applicable to the latter is applicable to the former as well. Obviously, however, because of the somewhat different objectives of the two business forms there are necessary differences which must be reflected in the law.

\section{THE MANAGEMENT OF CO-OPERATIVES}

\section{A. Distribution of Control}

The power to manage the affairs of co-operatives usually lies with the board of directors, either by virtue of the incorporating statute or by virtue of the internal rules of the corporation. In letters patent jurisdictions, the power to manage co-operatives is vested in the board of directors by statute. ${ }^{7}$ The Canadian registration statutes, however, are not silent on

2 In all there were nine Rochdale principles. They were:

(1) Open membership;

(2) Democratic control-the principle of one member, one vote;

(3) Limited interest on capital;

(4) Distribution of surplus in proportion to business transacted with the enterprise;

(5) Business conducted on a cash basis;

(6) Political and religious neutrality;

(7) Perpetuation of the co-operative philosophy through educative works;

(8) Sale of pure, high quality goods;

(9) Sale of goods at retail prices.

For a general history of the co-operative movement, including a discussion of its social and political background, see, Digby, The World Co-operative Movement (1960); also, Parker, The First 125 Years (1956).

3 The Co-operative Association Act, R.S.A. 1970, c. 67; Co-operative Associations Act, R.S.B.C. 1960, c. 77; Cooperative Associations Act, R.S.N.B. 1952, c. 40; The Co-operative Societies Act, R.S.Nfld. 1952, c. 172; Co-operative Associations Act, R.S.N.S. 1967, c. 57; The Co-operative Association Act, R.S.P.E.I. 1951, c. 32; Co-operative Associations Act, R.S.Q. 1964, c. 292; The Co-operative Associations Act, R.S.S. 1965, c. 246; Canada Co-operative Associations Act, S.C. 1970-71.72, c. 6. Hereinafter the primary co-operative statute from each jurisdiction will be referred to in the text simply by the name of the jurisdiction, e.g., the "Saskatchewan Act" or the "Ontario Act".

- The Corporations Act, R.S.O. 1970, c. 89, Part V; The Companies Act, R.S.M. 1970, c. 160, Part X.

s S.C. 1970.71 .72$, c. 6 [hereinafter referred to as the "Canada Act".]

- The first federal attempt to deal specifically with incorporation of co-operatives was made in 1908. Although a Bill was passed by the House of Commons, it was defeated in the Senate and thus never became the law of the country, see, Sen. Deb., July 15, 1908, at 1852. The Bill was entitled "An Act respecting Co-operation". It was defeated by Senate on the ground that, in the opinion of Senate, the federal government was acting outside its constitutional powers in passing the Bill. The Act of 1970 , id., therefore was the first federal co-operative legislation. In 1953 the Co-operative Credit Associations Act. S.C. 1952-53, c. 28 was passed but it only dealt with co-operative credit societies.

T See e.g., R.S.O. 1970, c. 89, s. 313(1). 
the point, as are some general corporation statutes which allow incorporation by registration, ${ }^{8}$ but vest the power to manage in the board of directors subject to the provisions of the association's internal rules.9 Thus, if the internal rules, variously called articles of association, by-laws or regulations, are silent, then the directors have the management power but residual power lies with the members or shareholders.10

The Canada Act vests the power of management with the directors. 11 But this power is not absolute and must be considered in conjunction with the power given to the general meeting to share in the management of the association. ${ }^{12}$ If the proper procedure of notice is followed, the general meeting can by ordinary resolution enact, amend, repeal or replace any by-law. This power takes precedence over the directors' power to pass bylaws which is effective only until ratification at the next general meeting. Perhaps a provision should have been included prohibiting reintroduction by the directors of by-laws rejected by the general meeting. Such a provision would prevent abuse of directors' powers in this respect. ${ }^{13}$

Some co-operative statutes recognize the role of director as being one of a supervisory nature, and not only a role of direct management. Of course the situation in many business associations is that directors act in an advisory or supervisory capacity and do not always manage the enterprise directly. One co-operative statute states that "directors shall direct and supervise the business and property of the association. . . ."14 However, the Ontario Act still retains a provision stating that "the affairs of every corporation shall be managed by a board of directors however designated."15 It has been recommended that this section be changed and brought in line with the corresponding provision in the Ontario Business Corporations Act. ${ }^{16}$ Such a change would more accurately reflect the realities of the situations.

\section{B. Directors}

\section{Qualification, Appointment and Removal}

The number of directors required by co-operatives varies from jurisdiction to jurisdiction. The lowest number of directors required in any jurisdiction is three, which is the minimum number required in Ontario. ${ }^{17}$ The concept of the one man corporation has not been adopted in cooperative legislation since it is inconceivable that a true co-operative could operate with only one member. Indeed, by definition, the word "cooperative" implies a plurality of members. It has been suggested in Ontario that the statutory minimum of three directors is too low, and it has been recommended that the minimum be raised to five persons, ${ }^{18} a$ minimum which accords well with the statutory requirements of several

E.g., the English Companies Act.

9.S.S. 1965, c. 246, s. 46; R.S.B.C. 1960, c. 77, в. 27(4); but see R.S.A. 1970, c. 67, s. $26\langle 7$ ).

10 See, M. Neuman, "Letters Patent and Memorandum of Association Companies", Ziegel ed., Studies in Canadian Company Law, (1967), 61 at $80-82$.

II S.C. $1970-71-72$, c. 6, s. 65.

12 Id., 88. 60, 61.

13 E.g., The Business Corporations Act, R.S.O. 1970, c. 53, 8. 21(4)[hereinafter sometimes referred to as the "Ontario BCA".]

14 R.S.S. 1965 , c. 246, s. 46.

is R.S.O. 1970, c. 89, 8. 313(1).

16 The Ontario Report, at 58; see R.S.O. 1970, c. 53, s. 132(1) which states: "The board of directors shall manage or supervise the management of the affairs and business of the corporation." (Emphasis added.)

17 R.S.O. 1970, c. 89, 8. 4.

18 The Ontario Report, at 59. 
other jurisdictions. The rationale underlying this recommendation is that a successful co-operative depends on member participation. A minimum of five directors, who are also members, would encourage this participation to a greater extent than a minimum of three directors.

Although recent corporate legislation has abandoned the requirement that directors must be shareholders, ${ }^{19}$ no co-operative legislation has adopted such a position. It is consistent with co-operative philosophy that the leaders of the enterprise also be member-patrons. However, a token membership may well be all that is required; therefore, a professional manager can easily qualify to hold a directorship. To prevent such a step some statutes allow the co-operative to require a director to conduct a minimum amount of business with the co-operative in order to qualify for or maintain office. ${ }^{20}$ One Act contains a mandatory provision to the effect that directors in agricultural co-operatives must sell their main crop through the co-operative. ${ }^{21}$ The Canada Act contains a typical provision relating to director qualifications. It states:22

No person shall be elected as a director of an association or appointed as a director to fill any vacancy unless he or a corporation of which he is an officer, director, member or shareholder, is a member of the association and he or such a corporation complies with any other requirements set out in the charter by-laws of the association.

The by-laws of the co-operative association usually set down the procedure for the election of directors, each member having only one vote, regardless of his holdings. Cumulative voting does not, of course, apply to co-operatives. However, it is common practice among co-operatives in the election of directors to require members to vote for each vacancy on the board, and failure to vote for a complete slate invalidates the ballot. ${ }^{23}$

The procedure for removal of directors from office varies in different jurisdictions. The Quebec Co-operative Agricultural Associations Act ${ }^{24}$ does not contain any provisions allowing for the dismissal of a director before his term expires, while other statutes entrench the right to removal by a two-thirds majority vote at a general meeting. ${ }^{25}$ The Ontario Act states that the corporate constitution may provide for the removal of a director by a two-thirds vote at a general meeting called for the purpose. ${ }^{26}$ for: ${ }^{27}$

The Canada Act requires that the charter by-laws make provision

The qualification of directors and the method of appointing directors or of making nominations and holding elections for directors, the procedure for counting ballots and all other matters or things relating to the conduct of elections of directors, the terms of office of directors and the procedure for removal thereof.

Thus control over the entire directorial regime and the terms of its mandate is given to the members, subject to one important exception. Under the Act, a charter by-law is one that has received approval by the Minister. ${ }^{28}$ Thus ministerial discretion impinges on the internal workings

\footnotetext{
19 E.B.. R.S.O. 1970, c. 53.

20 R.S.A. 1970 , c. 67 , s. $26(5)$; R.S.S. 1965 , c. 246 , s. 72 ; R.S.N.B. 1952, c. 40, s. 36; R.S.P.E.I. 1951 , c. 32 , s. 27.

21 R.S.B.C. 1960 , c. 77 , 8. 24(10).

22 S.C. $1970-71-72$, c. $6,8.63$.

23 The Ontario Report, at 60 . To allow cumulative voting would have the effect of giving a member more than one vote and thus breach the basic co-operative principle of one member, one vote. The Ontario Act exempts co-operatives from its cumulative voting provisions, R.S.0. 1970, c. 89, 8. 66(2).

24 R.S.Q. 1964, c. 124

25 R.S.S. 1965, c. 246, 8. 53.

25 R.S.O. 1970, c. 89, 8. 68(1), 134(1).

${ }^{27}$ S.C. $1970-71 \cdot 72$, c. 6 , s. $11(2)(i)$.

2s Id. 8s. $3(1)(\mathrm{b}), 60(4)$.
} 
of the co-operative. This discretion was given the Minister for the purpose of protecting co-operative status. It appears that, consistent with this rationale, by-laws requiring his approval should receive it as a matter of course unless the by-law, or its amendment or repeal, affects the "cooperative basis" 29 of the organization.

\section{Duties}

As with other corporations, in the absence of statutory regulatory provisions, the rules governing the duties owed by directors to the corporation are gleaned from the cases. Also, as with ordinary business corporations, the ambit of statutory regulation vis-a-vis director's duties has not been broad. Indeed, such provisions in co-operative statutes are more scarce than in general corporation statutes.

The Canada Act, which comprises the most recent co-operative legislation in Canada, contains more provisions governing directors than any existing Canadian co-operative legislation. However, notwithstanding its lead in attempting to legislate objective standards, the draftsmen could have followed recent general corporate legislation to a greater extent. ${ }^{30}$ The Canada Act is conspicuously silent with regard to the standard of care required of directors and perhaps somewhat deficient in its treatment of insider trading. It is also silent with regard to directors' duties of good faith and interception of corporate opportunities, but perhaps more justifiably so in that cogent arguments can be made in favor of allowing this to be an area free of elaborate legislative control..$^{31}$ However, a general provision should have been inserted which stated the general duty of loyalty and good faith illustrating the fiduciary principles governing the position of directors.

\section{(a) The Duty of Care and Skill}

None of the co-operative statutes in Canada attempt to codify the minimum standard of care a director is required to observe in the exercise of his duties. Thus the required standard of care is identical with that required of directors of ordinary business corporations under the common law, since there has been no jurisprudence which distinguishes cooperatives on this point. Although recent corporate statutes have contained provisions which attempt to clarify and objectify the standard required of directors, it is questionable whether the absence of similar provisions in co-operative legislation, including the relatively recent Canada Act, is a deficiency.

To state that the common law governing the area is "a sea of murky jurisprudence", as did the Lawrence Committee, ${ }^{32}$ is perhaps overstating the case somewhat although the common law may be in an unsatisfactory state. Any statutory reform should make a significant improvement, but recent attempts have not done so.

The Ontario BCA contains the following provision: ${ }^{33}$

29 Id. ss. $3(1)(d), 5(1)$.

3o The Canada Co-operative Associations Act was assented to December 18th, 1970 and was drafted subsequent to Ontario's Bill 125 which resulted in the Ontario Business Corporations Act. However, although the draftsmen could have followed the progressive approach taken in the Ontario BCA, on the whole they were content to deviate little from the Canada Corporations Act in dealing with the responsibilities of directors.

${ }^{31}$ See, Proposals for a New Business Corporations Law (Can. 1971) Vol. I, para. 237 (hereinafter referred to as the "Canada Proposals"].

32 Interim Report of the Select Committee on Company Law (Ont. 1967) 53.

33 R.S.O. 1970, c. 53, s. 144; see also the Canada Business Corporations Act, S.C. 1974-75, c. 33, s. 117. 
Every director and officer of a corporation shall exercise the powers and discharge the duties of his office honestly, in good faith and in the best interests of the corporation, and in connection therewith shall exercise the degree of care, diligence and skill that a reasonably prudent person would exercise in comparable circumstances.

Although the above provision makes the test a more objective one, it may have the effect of lowering the common law standard of care in certain cases. The common law dictates a partially subjective standard, taking into account the director's knowledge and experience. ${ }^{34} \mathrm{By}$ failing to do this, the above quoted section may in effect require a lower standard of conduct from a well qualified director than would be demanded under the common law. Perhaps the use of the words "reasonably prudent director" in the section, rather than "reasonably prudent person" would raise the standard somewhat. ${ }^{35}$ However, the word "diligence" included in the section implies a requirement to attend meetings, which is an improvement over the common law. ${ }^{36}$

The inclusion of a statutory standard of care in co-operative statutes would take cognizance of the fact that many boards of directors are composed of professional business managers, as well as lay directors. A statutory requirement of care and skill should be flexible enough to ensure a reasonable level of competence from both types of directors. A test which uses the "reasonably prudent person" as the point of reference surely is too relaxed when applied to a professional director. Unless the legislatures are willing to recognize this, the needs of co-operatives may be served as well by continuing to apply the common law standard.

\section{(b) Fiduciary Duties}

No attempt has been made to codify the law relating to the fiduciary duties of loyalty and good faith of directors in any of the co-operative statutes. Nor has any co-operative legislation even attempted a general statement outlining the fiduciary principles governing such duties as has been done in some general corporation statutes, that is, a provision to the effect that the directors must act honestly, in good faith and in the best interests of the corporation. ${ }^{37}$ However, two jurisdictions, Prince Edward Island and Alberta, require directors to be loyal to the co-operative. The Alberta Act states: ${ }^{38}$

If a director is, to the satisfaction of the board, proved to be guilty of disloyalty to the association without adequate cause being shown to the satisfaction of the board, the board may by resolution declare his office vacant and the vacancy so created shall be filled by appointment by the remaining directors.

Such loyalty requirement surely must be interpreted to mean that the direc-

34 In Re City Equitable Fire Insurance Company Limited [1925] Ch. 407 (C.A.); Western Ontario Gas Company v. Aitkens et al. [1946] O.R. 661 .

${ }^{35}$ See, Iacobucci, The Business Corporations Act, 1970: Management and Control of a Corporation, (1971) 21 U. of T. L.J. 543 at 551.

36 Id. at 552; although the common law requirement to attend meetings has been applied very loosely, see In Re Denham \& $C_{0}$. (1883) $25 \mathrm{Ch}$. D. 752 and The Marquis of Bute's Case[ 1892] $2 \mathrm{Ch}$. 100-in both cases directors had not attended meetings for over four years and no liability accrued to them; this is not necessarily the result arising from the test laid down by Romer J. in the leading case of In Re City Equitable Fire Insurance Company Limited, supra, n. 34. Romer J.'s statement can be interpreted as requiring a stricter standard than was applied in the two above noted cases. He said at 429: "A director is not bound to give continuous attention to the affairs of his company. His duties are of an intermittent nature to be performed at periodical board meetings, and at meetings of any committee of the board upon which he happens to be placed. He is not, however, bound to attend all such meetings, though he ought to attend whenever, in the circumstances, he is reasonably able to do so." The Ontario BCA, R.S.O. 1970, c. 53, s. 137(3), assumes an absent director has consented to certain resolutions at board meetings unless he records his dissent; see also the broader provision of the Canada Business Corporations Act, supra n. 33, s. 118 and the Canada Proposals, Vol. II, s. 916(3).

37 See, supra, n. 33.

ss R.S.A. 1970, c. 67, s. 26(11). 
tors must act in the best interests of the association and honestly and in good faith. However, a more explicit statement to that effect would be desirable.

The remedy provided in the section quoted above hopefully would not be exhaustive of the co-operative's rights, should a director be in breach of good faith. The common law, as it applies to ordinary business corporations, would be applicable here. If a director has taken advantage and profited from an opportunity which rightfully belonged to the corporation, the corporation has a right to bring an-action to force him to disgorge such profits. The law relating to this aspect of director's duties is complex and is currently the subject of judicial consideration ${ }^{39}$ and doctrinal comment. ${ }^{40}$ The point to be made is that, although there are no reported cases in which the issue of directors' fiduciary duties has directly arisen with respect to co-operatives, there is no inherent reason why co-operative directors should be treated any differently than directors of ordinary business corporations. Both perform essentially the same function, and any abuse of office should have the same legal result.

Some co-operative statutes have attempted to regulate specific aspects of directors' conduct where conflict of interest situations may arise. Two such areas are: (1) directors' contracts with the co-operative, and (2) insider trading.

\section{(i) Duty to Disclose Interest in Contracts}

Most provincial Acts are silent with regard to the enforceability of contracts made between directors and their co-operatives, again leaving the matter to be governed by common law. The common law dictates that a contract between an interested director and a corporation of which he is a director is voidable at the instance of the corporation and the director must account to the corporation for any profits made by him personally. ${ }^{41}$ The fairness of the contract to the corporation is irrelevant.42 Unless the corporate constitution creates alternate machinery to exonerate an interested director, the only course open to him is to make full disclosure to the members of the corporation and to have the contract ratified by the general meeting. Disclosure only to the board of directors is ineffective notwithstanding the fact that the interested director may refrain from voting. ${ }^{43}$

The Saskatchewan and Manitoba co-operative statutes contain sections regarding directors' contracts. The former jurisdiction requires disclosure to the general meeting of "any contract for profit with the association that confers ... any rights other than such as are accorded to members generally." 44 The problem is to determine what rights are "accorded to members generally." Presumably this means contracts with the cooperative to supply the goods and services which are in the nature of the cooperative's business. However, could the provision be interpreted as referring only to those contractual rights contained in the corporate constitution which are binding on all the members? ${ }^{45}$ If this is the proper interpretation

${ }^{39}$ Canadian Aero Service Ltd. v. O'Malley et al. (1974) 40 D.L.R. (3d) 371 (S.C.C.); Peso Silver Mines Ltd. (N.P.L.) v. Cropper [1966] S.C.R. 673; 58 D.L.R. (2d) 1; 56 W.W.R. 641. Also see, Regal (Hastings) Ltd. v. Gulliver et al. [1942] 1 All E.R. 378; Zwicker v. Stanburyet al. [1953] 2S.C.R. 438;[1954]1 D.L.R. 257; Boardman v. Phipps [1967] 2 A.C. 46.

10 Beck, The Saga of Peso Silver Mines: Corporate Opportunity Reconsidered, (1971) 48 Can. Bar Rev. 80; Prentice, Directors' Fiduciary Duties - The Corporate Opportunity Doctrine, (1972) 50 Can. Bar Rev. 623.

11 See, Gower, The Principles of Modern Company Law (1969) 527, 552.

42 Aberdeen Railway v. Blaikie Brothers (1854) 1 Macq. (H.L.) 461; 149 R.R. 833; [1843-60] All E.R. Rep. 249.

43 Imperial Mercantile Credit Association v. Coleman (1871) L.R. 6 Ch. App. 558 at 567.

4 R.S.S. 1965, c. 246, s. 50.

45 Id. 8. 13. 
the section is excessively restrictive. The ambiguity of the section is not desirable and a more specific provision similar to that contained in the Canada Act ${ }^{46}$ would be preferable. The Manitoba Act ${ }^{47}$ contains a similar provision to that of Saskatchewan. However, it goes one step further by prohibiting absolutely directors' contracts with the co-operative that are not in the nature of those accorded to members generally. Disclosure and ratification by the general meeting will not exonerate an interested director. Thus the position under the Manitoba Act is more restrictive than the common law position.

Co-operative directors should have at least the freedom of contract of directors of ordinary business corporations. Indeed, because of the nature of a co-operative enterprise which envisages its owners and operators to also be its patrons, co-operative directors perhaps require more latitude in dealing with the association than their counterparts in ordinary business corporations. The Canada Act contains the most elaborate provision dealing with co-operative directors' contracts. Section 73 contains a disclosure provision which excludes all marketing contracts, service contracts, and contracts to purchase goods from the co-operative that are similar to contracts entered into by the co-operative with ordinary members. The Act recognizes the special needs of co-operatives in this respect. The excluded transactions can be entered into by directors without the need to disclose to anyone and without the fear of having the transaction avoided.

Other contracts are caught by the disclosure provision which is otherwise virtually identical to that contained in the Canada Corporations Act. 48 The procedure is streamlined compared to the common law requirement. Disclosure need only be made to the board of directors and the interested director must refrain from voting on the contract. If the procedure is complied with, the director is not accountable for any profit he may realize on the contract. Section 73 also carries over the general disclosure provision contained in the Canada Corporations Act ${ }^{49}$ which allows the director to make one blanket declaration of interest to the effect that he has an interest in a firm or association. With such a declaration any subsequent contracts the co-operative enters into with the disclosed firm or association will be valid. Also, the co-operative in general meeting may confirm any contract and exonerate a director from liability notwithstanding failure to comply with the proper procedure.

Under section 73 all contracts, save those expressly excepted, must be declared. There is no requirement of materiality such as exists in a similar provision in the Ontario BCA. ${ }^{50}$ Any problems as to what contracts are to be considered material are avoided. All interests must be declared and the interested director cannot plead that the contract in question was not sufficiently material to be disclosed. However, the value of the certainty obtained is perhaps offset by the fact that even very minor interests must be declared. In practice this may prove to be inexpedient.

Also section 73 simply requires that an interested director "declare his interest". A more complete disclosure may be desirable and could be effected by requiring disclosure of the "nature and extent" of his interest. Such a re-

16 S.C. 1970-71-72, c. 6, s. 73, see infra for a discussion of 8.73 .

47 R.S.M. 1970 , c. 160 , s. 421 .

4 R.S.C. 1970 , c. C-32, s. 98.

49 Id.

so R.S.O. 1970, c. 53, s. 134; see also, the Canada Business Corporations Act, supra n. 33, s. 115; but see the Canada Proposals, Vol. II, s. 9.17 which excluded the requirement of "materiality". 
quirement is contained in recent general corporation statutes. ${ }^{51}$ Such a requirement exists in section 72 of the Canada Act which pertains to disclosure of discovery of serious impairment of capital by the directors. One may only speculate at the reasons why the words were excluded from section 73. It is obvious that the draftsmen simply transcribed the section directly from the Canada Corporations Act with no apparent consideration given to the more progressive corporate legislation in existence at the time of drafting.

Two further observations can be made regarding section 73 of the Canada Act. The wisdom of allowing a continuing disclosure may be questioned. The Ontario BCA does not allow such a blanket declaration, but requires a specific disclosure of the nature and extent of the interest of a director in every material contract the corporation transacts with him or his firm. Allowing a general disclosure may in effect provide a camouflage to hide transactions which the co-operative should have specified.

Also, there is no overriding requirement that the contract be "reasonable and fair to the corporation"52 or that "it was in the best interest of the corporation." 53 Such a requirement "is necessary to preclude mutual 'backscratching' by directors who might otherwise tacitly agree to approve one another's contracts with the corporation." 54

\section{(ii) Insider Trading}

Only two provincial Acts have provisions requiring insiders of cooperatives to file reports of ownership and change of ownership of securities. In Ontario and Manitoba, where no separate co-operative incorporating statutes exist, the provisions of the general Act regarding insider trading apply to some co-operatives. But in both jurisdictions the provisions appear to be only applicable to co-operatives with share capital and not to cooperatives without share capital since the word "company", as used in both Acts, is defined as meaning a corporation with share capital ${ }^{55}$ and only an insider of a "company" need file reports. ${ }^{56}$

It has been argued that the requirement to file insider reports should not extend to insiders of a co-operative. ${ }^{57}$ The reasons supporting this position are: (1) Regardless of the number of shares he holds, a co-operative member has only one vote. Thus a member holding ten or fifteen percent of the voting shares is no more able to influence the conduct of the affairs of the cooperative by his voting power than a member with only one share. ${ }^{58}$ (2) Several factors contribute to the absence of any significant market in the shares of a co-operative. Some such factors are: co-operative shares do not fluctuate greatly in value, are subject to a dividend limit, are subject to repurchase or redemption, and transfers of shares require the approval of the board of directors.

Notwithstanding the above arguments, it has been recommended in Ontario $^{59}$ that, although insiders of co-operatives should not be required to file

\footnotetext{
si Id.

32 Canada Business Corporations Act, supra n. 33, 8. 115; The Canada Proposals, Vol. II, 8. 9.17(3).

s3 R.S.O. 1970 , c. 53 , 8. 134(4).

54 The Canada Proposals, Vol. I, para. 228.

ss R.S.O. 1970 , c. 89 , в. 1 (c); R.S.M. 1970 , c. 160 , в. $2(1)(d)$.

s6 Id. s8. $73(1)($ e), 74 ; R.S.M. 1970 , c. 160 , s. 86.

57 Ontario Report, at 62.

58 Note however the Canada Act does not necessarily require that members only have one vote, S.C. 1970-71-72, c. 6, 8s. $3(1)(d), 5(1), 58$; see infra text at $n .96$.

s9 Ontario Report, at 64.
} 
reports with the Ontario Securities Commission, a provision similar to the section imposing liability on insiders in the Ontario $\mathrm{BCA}^{60}$ be implemented. Thus, the insiders of all co-operatives would be liable to compensate any person for direct loss resulting from the use of specific confidential information in connection with a transaction relating to the securities of the co-operative and would be accountable to the co-operative for any direct benefit or advantage resulting therefrom. However, the recommendation has not yet been implemented.

The Canada Act contains a section dealing with insider trading but adopts an approach different from that recommended in Ontario. Section 75 of the Canada Act simply requires a director to file with the association's secretary, prior to each annual meeting, a detailed statement of all transactions in the securities of the co-operative, since the filing of the last statement, to which he was a party for his own account, either directly or indirectly. Such disclosures are then to be made available for inspection by the members. Failure to comply with section 75 renders one liable to a maximum penalty of a $\$ 1,000$ fine and/or six months imprisonment. The section applies to officers of the co-operative in addition to the directors.

Section 75 appears to be a token attempt to regulate insider trading. There is no civil liability provision making a guilty insider liable to someone who has suffered a financial loss as a result of the former's activities. Thus an injured party appears to have no remedy. The Canada Act has fallen far short of the double liability provisions of comparable corporate legislation. Also, although indirect benefits accruing to directors and officers are covered by the section, no attempt is made to make more certain what is meant by "indirect". The section could easily have followed the other corporate legislation by rendering directors and officers liable for benefits obtained by associates and affiliates and by offering a definition of "associate" and "affiliate."61

Also section 75 only applies to officers and directors and not to holders of a substantial amount of shares, such as a $10 \%$ ownership requirement as is contained in other insider legislation. However, as suggested above, such a provision may not be necessary in a co-operative where voting power is not coincident with shareholding. But the Canada Act does not entrench the requirement of co-operative members only having one vote regardless of shareholding; thus perhaps consideration should have been given by the draftsmen to extending the ambit of the section to substantial shareholders.

\section{COOPERATIVE MEMBERSHIP}

\section{A. Admission}

Although the Rochdale pioneers included open membership as a basic principle of co-operation, ${ }^{62}$ no such requirement is contained in any Canadian co-operative legislation. Full open membership cannot be practised when there exist co-operatives with very specific functions which require members only from a very limited element of the community who share an interest related to the function of the association. For example, hog marketing co-operatives should be allowed to limit membership to producers of hogs; persons outside of this limited group should not have an absolute right to membership. Such limitation of membership is provided for in

\footnotetext{
6 R.S.O. 1970, c. 53, в. 150.

61 E.g., id. ss. 1(1)1., 1(1)3., 150.

62 Supra, n. 2.
} 
various statutes with some measure of flexibility. The Saskatchewan Cooperative Marketing Associations Act contains a section limiting membership in a co-operative incorporated thereunder to persons directly or indirectly engaged in the production of products to be handled by the association. ${ }^{63}$ However, the provision allows membership to "such other persons as obtain title to or possession of products by due process of law." Consumers of the product handled by the association can therefore become members and have a voice in its operation.

It is common for co-operative statutes to allow the co-operative to make its own rules regarding admission of members and to require director approval of new members.64 Clearly the principle of open membership has not received statutory enshrinement in Canada. Indeed the co-operative movement itself has recognized the problems inherent in the principle of open membership. In 1966 the International Co-operative Alliance in its reformulation of basic co-operative principles did not insist on an unlimited right to membership but stated that: 65

Membership of a co-operative society should be voluntary and available without artificial restriction or any social, political or religious discrimination, to all persons who can make use of its services and are willing to accept the responsibilities of membership.

Although director discretion in admission of members is necessary to make the initial determination of qualifications of applicants, perhaps certain limitations on the directorial discretion could be imposed by statutes in an attempt to ensure fairness. On the other hand, however, such civil rights legislation should not perhaps be included in co-operative legislation but left to the appropriate human rights statutes.

Most provincial co-operative statutes provide a minimum age at which persons may become members and most stipulate that age to be sixteen years. ${ }^{66}$ The Canada Act has adopted the sixteen years minimum as well. ${ }^{67}$ Presumably, then, minors sixteen years of age and over who are members are bound by the terms of the corporate constitution. ${ }^{68}$ However, none of the statutes indicate the status of a minor member with regard to contracts he has with the association. A provision should be inserted to the effect that minor members are competent to enter into such contracts with the association and are sui juris with respect to the contracts.

The Ontario Act is silent on the age at which a person may become a member of a co-operative. It has been recommended however that the Act be amended to conform with other provincial statutes and to clarify the status of contracts with minor members. 69

\section{B. Termination: Withdrawal and Expulsion}

When a member no longer uses the services provided by his co-operative, perhaps because he has retired or has moved from the area, he may wish to withdraw from the association and recover his investment. That he should have the right to withdraw is undeniable, but the question is whether that right should be unqualified. To allow complete withdrawal at any time may

\footnotetext{
os R.S.S. 1965, c. 247, s. 19.

o4 Id.; also R.S.O. 1970, c. 89, 8. 130 and S.C. 1970-71-72, c. 6; 83. 38, 39.

os Report of the Commission on Co-operative Principles to the 23rd Congress of the International Co-operative Alliance (1966), reproduced in the Ontario Report, Appendix A, p. 101.

${ }_{66}$ Only New Brunswick atipulates that the minimum age for membership is 21 years, R.S.N.B. 1952, c. 40, 8. 18, although the association may by supplementary by-law reduce the age to not less than sixteen years.

67 S.C. $1970-71.72$, c. 6, 8. 39(5).

6 E.g., id. s. 39(6).

60 The Ontario Report, at 53.
} 
result in the co-operative suffering as a result of much needed capital being removed from its coffers. The interests of the co-operative must also be protected when the rights of the member are being exercised.

Most co-operative legislation provides that the co-operative prescribe the procedure for withdrawal of members in its by-laws. ${ }^{70}$ The association can then impose certain limitations upon the withdrawal and the corresponding return of capital through a purchase of shares by it. Such limitations may include notice of intention to withdraw and a time period over which the redemption may take place. By allowing itself time to repurchase the shares the co-operative may take steps to obtain capital to replace the funds returned to the member. In this way it may avoid a potential financial crisis in the instance where the member's contribution to the capital fund represented a substantial portion of the total fund.

Some statutes, such as the Saskatchewan Act and the Canada Act, outline the withdrawal procedure to be followed in the absence of by-laws to that effect ${ }^{71}$ while others, such as the Ontario Act, are totally silent regarding an alternate procedure. ${ }^{72}$ In Ontario the entire matter would be left within the discretion of the directors, failing provision for the same in the by. laws, creating somewhat of an uncertain and a potentially unhappy situation.

Perhaps the best solution would be to entrench in the statutes certain rights of the member upon withdrawal. The rights contained in the above noted statutes ${ }^{73}$ allow the co-operative to suspend payments for shares for a period not exceeding one year where the financial stability of the association would be impaired by the withdrawal. ${ }^{74}$ The member who wishes to withdraw therefore will not have his capital detained indefinitely. However, those procedures are only applicable if the by-laws are silent on the point and they do not guarantee fair treatment to the member if the procedure in the by-laws is oppressive. Of course it may be argued that he freely consents to the terms of the by-laws upon becoming a member or that subsequent changes in the by-laws require shareholder approval in general meeting thus guaranteeing a member representation at least. ${ }^{75}$ Nonetheless it is suggested that the statutes should contain a provision setting out a maximum period in which the association must purchase the member's shares which would take precedence over any provision in the by-laws.

Under the Canada Act if a co-operative wishes to prescribe the withdrawal procedure it must do so by charter by-law and not by ordinary by-law. ${ }^{76}$ This allows the Minister to oversee the procedure proposed and possibly refuse to approve the by-law if the procedure is unduly oppressive. ${ }^{77}$ Whether the Minister's discretionary power will be used in this manner remains to be seen.

Related to the voluntary termination of membership is the right of the cooperative to expel a member. The association may want to exercise this right in a number of situations including the situation where a member has ceased to be an active member utilizing the co-operative's services, or where a

\footnotetext{
70 E.g., R.S.O. 1970 , c. 89, в. 130; R.S.S. 1965, c. 246 , в. 30; S.C. 1970.71 .72 , c. 6, s. 49.

7 R.S.S. 1965 , c. 246 , s. 30; S.C. $1970.71-72$, c. 6, s. 49.

72 R.S.O. 1970 , c. 89, s. 130.

73 Supra, n. 22.

24 However upon approval of the Registrar under the Saskatchewan Act, or the Minister under the Canada Act, the period may be extended.

${ }^{73}$ E.g., S.C. 1970-71-72, c. 6, 8. 61(2).

70 Id. 8. $49(1)$.

n Id. s8. 3(1)(b), 60(4).
} 
member has breached the terms of the by-laws or perhaps where he generally has had a disruptive influence on the organization. The conditions for expulsion vary among the jurisdictions but are contained either in the statute $^{78}$ or in the by-laws.

The Canada Act has adopted provisions regarding compulsory termination at the option of the association that are not uncommon. ${ }^{79}$ The statute allows the co-operative to purchase a member's shares where: (1) he has failed to transact any business with the association for a period of two years or; (2) where a member is a corporation that is about to be dissolved.80 Otherwise there is no entrenched statutory right to terminate membership. However, the association may pass a by-law authorizing the board of directors to expel a member by a two-thirds vote of the board. ${ }^{81}$ The Act does not contain a statement of offences or breaches which may be grounds for expulsion but requires this to be governed by the articles of association or the charter by-laws. ${ }^{82}$ Also the exact procedure for expulsion is not outlined in the $\mathrm{Act}^{\mathrm{83}}$ but certain rights are guaranteed the outcast member. Written reasons for the expulsion must be given to the member and the member must be afforded an opportunity to be heard. If an expulsion order is made the Act guarantees the return of the member's investment within a twelve-month period save an extension being granted by the Minister. Any extension by the Minister must not exceed a further period of twelve months and any subsequent extensions can only be granted by the court. Finally, the member has a right to appeal a directors' expulsion resolution to the general meeting but there is no statutory right to appeal it further to a court.

Unlike the procedure outlined in the provisions dealing with voluntary withdrawal, ${ }^{84}$ the rights contained in section 51 of the Canada Act are entrenched and are not only alternatives to any rights provided in the co-operative constitution. This distinction is perhaps justified, for in the instance of withdrawal the member is subjecting himself voluntarily to the termination procedure outlined in the corporate documents, whereas in the instance of expulsion the same voluntariness is absent. However, as previously argued, the statute should guarantee minimum rights in both instances of termination of membership regardless of the method by which that termination is brought about.

Although other co-operative statutes may not contain a provision guaranteeing an expelled member the opportunity to be heard by the board of directors, such a right appears to exist by virtue of a Supreme Court of Canada decision. In Marcotte v. La Société Cooperative Agricole de SteRosalie $^{85}$ the Court considered the principle of audi alteram partem as it applies to a co-operative member. Although the member's appeal was unsuccessful in this instance, Mr. Justice Abbott clearly recognized that the member had a right to appear before the board of directors of the cooperative before he was struck off the membership roll. The plaintiff, Marcotte, was a member of a co-operative incorporated under the Co-operative Agricultural Associations Act of Quebec. ${ }^{86}$ He entered into a contract with

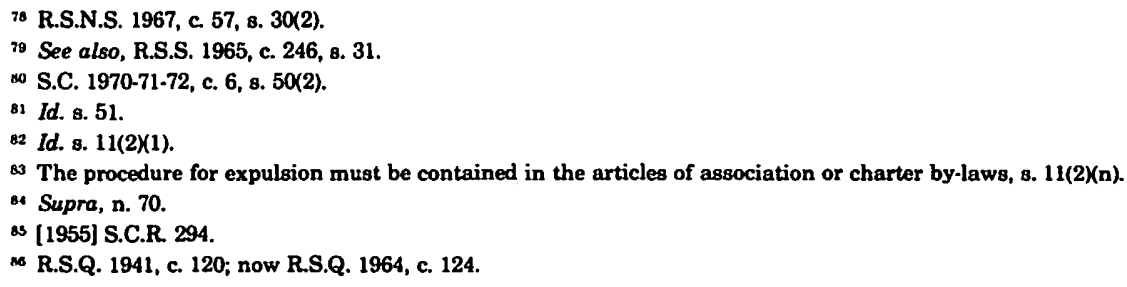


the association under which he agreed to purchase from the association all feed, seed, grain and chemical fertilizer which he might require. The contract and the Act ${ }^{87}$ authorized the expulsion of any member who breached the terms of the contract. Marcotte allegedly did breach the terms of the agreement by purchasing his supplies elsewhere and as a consequence thereof was expelled from membership in the association. The Court's judgment proceeded on the basis that Marcotte had a right to present his case to the board of directors before an expulsion order became effective. The appeal failed because he did not plead the fact of no hearing before the court of first instance but only raised the point at the Court of Appeal level. Abbott J. stated:88

Assuming that the Board of Directors of the Association was acting in a quasi-judicial capacity, the failure to hear or to summon the appellant before adopting the resolution in question was in my opinion a question of fact which should have been expressly pleaded if appellant wished to rely upon it in his action.

Perhaps a general provision could be included in the co-operative statutes allowing a right of appeal to a court from a decision of the board of directors regarding termination of membership, including the actual termination itself if involuntary on the part of the member (expulsion) and directors' decisions regarding return of investment once the procedure of termination has commenced. However, it seems that the two matters could be separated for such appeal purposes. Although there are possibilities for abuse of the directors' power of expulsion, under the Canada Act such decisions can be appealed to the general meeting ${ }^{89}$ on the merits and perhaps that is where the matter should stop. Although the particular member may not have been treated entirely fairly by the association, to ensure the smooth operation of the association the members' decision should be final. However, with regard to the return of the member's investment a right to appeal to a court should be given in the statute to safeguard against abuse of his rights. This right of appeal could be given in addition to entrenched rights, as suggested above, or in lieu of such rights. At least one of the safeguards should be adopted in order to protect the member in the somewhat precarious situation he may find himself upon the termination of his membership in the co-operative.

\section{Voting}

Reflecting the non-investment nature of co-operatives, the Rochdale pioneers included the principle of one member, one vote in its formulation of basic co-operative principles rather than voting being weighted in direct relation to a member's financial investment in the association. This principle is entrenched in all the Provincial Acts. Also all the Provincial cooperative statutes contain a prohibition against proxy voting. ${ }^{90}$ This prohibition is based on the premise that democratic control involves decision making after a full discussion of the members and this requires voting in person and not by proxy.

Although it has been generally accepted that voting rights in co-

87 Id. 8. 14.

Bs Supra, n. 85 at 298.

B9 S.C. $1970.71-72$, c. 6 , s. $51(1)$ (c).

* E.g., The Ontario Act, R.S.O. 1970, c. 89, s. 148 states:

148. (1) No individual member or shareholder of a corporation shall vote by proxy.

(2) An individual member or shareholder of a corporation has only one vote.

(3) A corporate member or shareholder may appoint under its corporate seal one of its directors or officers to attend and vote on its behalf at meetings of members or shareholders and such director or officer has only one vote. 
operatives should be separated from investment, it has been suggested, but not adopted, that perhaps voting rights be weighted according to a member's patronage with the association. ${ }^{91}$ Such a provision would ensure that those members using the co-operative are indeed those who make the decisions. However, the right to expel a member after two years of nonparticipation $^{92}$ partially solves the problem of representation by non-active members.

Although the proxy prohibition is designed to further the democratic process, it may have the contrary effect in the case of co-operatives with members spread throughout a large geographical area. In such cases the members may not be able to attend general meetings personally yet they are prohibited from appointing a personal representative to exercise a vote on their behalf. In recognition of such problems arising, many enabling statutes permit co-operatives to organize a delegate system of voting. ${ }^{93}$ The mechanics of the delegate system of voting have been described as follows: ${ }^{94}$

... the membership of the co-operative is divided into zones or branches, and the members of each zone or branch are entitled to elect a specified number of delegates to attend meetings. The number of delegates which a zone or branch is entitled to elect may depend on either the number of members in each zone or branch or the volume of business transacted with the co-operative by the members of the zone or branch or both. Zone or branch meetings are held at which the members of the zone or branch elect their delegates to attend meetings of shareholders and at which the affairs of the co-operative are discussed. In effect, a zone or branch meeting is more or less the equivalent of a local annual meeting.

If a co-operative wishes to institute a delegate system (in the jurisdictions where it is permitted) it simply passes by-laws to that effect.

It is questionable whether the delegate system of voting is preferable to the simple use of proxies if the ultimate aim of the co-operative is democratic control. Also it certainly is not clear that delegate voting accords well with the principle of one member, one vote. The tiered system of delegate voting seems to move the member one step further away from participation in the affairs of the co-operative than does the appointing of a proxy. The latter means has the advantage of giving the member a more direct voice in the operation of the association. One provincial Act has adopted a restricted proxy provision which may be a better solution than either full proxy rights or absolute prohibition of proxy voting. The British Columbia Act allows a member to vote by proxy if he resides more than fifty miles from the place where operations of the business are carried on. ${ }^{95}$

The Canada Act has eroded the principle of one member, one vote and the prohibition against proxy voting. Section 58 contains the requirement that each member has only one vote but such requirement is subject to the charter by-laws of the association. Also "co-operative basis" is defined as an enterprise organized upon certain principles, including, inter alia, "except in the case of an association the charter by-laws of which otherwise provide, each member or delegates has only one vote."96 The voting rights of members and delegates must be provided for in the draft charter by-laws which are filed with the Minister when incorporation is sought ${ }^{97}$ and thus must receive

\footnotetext{
91 The Ontario Report, at 48. Some American states have legislation permitting voting on such a basig, e.8., New York Cooperative Corporations Law, N.Y.C.L. c. 77, 8. 12.

92 Supra, n. 79, 80.

20 R.S.O. 1970, c. 89, 8. 155; R.S.A. 1970, c. 67, 8. 28; R.S.S. 1965, c. 246, 88. 61, 62; R.S.B.C. 1960, c. 77 , 8. 26.

24 The Ontario Report, at 50.

${ }^{23}$ R.S.B.C. 1960 , c. 77 , s. $24(3)$.

S.C. $1970-71-72$, c. 6, 8. 3(1)(d)(i).

07 Id. 8. 11(2)(e). (Emphasis added).
} 
ministerial approval.98 Exactly how much latitude the Minister will allow co-operatives when establishing their voting systems is not known. But at least in theory there is no prohibition against linking voting power with investment to the point of making co-operatives incorporated thereunder indistinguishable from ordinary business corporations in respect of voting. Presumably, however, consistent with the discretionary powers under the Act given to the Minister to preserve co-operative status, ${ }^{99}$ the latitude given co-operatives may only allow them to provide for voting based on patronage rather than establishing voting machinery totally inconsistent with cooperative philosophy. Such provisions linking voting with patronage would not be inconsistent with co-operative philosophy and indeed may be desirable.

Also the general prohibition against proxy voting contained in section 58 of the Canada Act is subject to the charter by-laws. However, it seems that the charter by-laws cannot provide for complete freedom of proxy voting but can only allow proxy votes in regard to the election of directors. ${ }^{100}$ Again Ministerial discretion comes into play and the latitude which will be allowed regarding proxy voting in the charter by-laws is not known. It is conceivable that in practice limits on proxies for the election of directors may be similar to those contained in the British Columbia Act. ${ }^{101}$

\section{Members' Other Rights}

Under the Canada Act, as in other co-operative statutes, annual meetings must be held.102 The general meeting can by ordinary resolution enact, amend, repeal or replace any by-law if a written notice of the proposed resolution has been forwarded to each member with the notice of the meeting. Failing such notice a special resolution is required to alter the bylaws. ${ }^{103}$

Under the Act one fifth of the members may requisition the directors to call a special general meeting whereupon the directors must proceed to do so within twenty-one days. ${ }^{104}$ If the directors fail to call the meeting the requisitionists may do so themselves. The Act is not dissimilar to the Ontario BCA in this respect. ${ }^{105}$ If the requisitionists do in fact incur the expenses of calling the meeting they may recover any reasonable expenses from the association and the right to recover is not contingent upon a shareholder or member vote. ${ }^{106}$

The business to be considered at any meeting is determined by a majority of the members unless otherwise provided. Section 79(3) of the Canada Act states:

In the absence of other provisions in that behalf in this Act or the by-laws of an association, all questions proposed for the consideration of the members at any meeting of members of the association shall be determined by a majority of votes, and the chairman presiding at any such meeting has a casting vote in case of an equality of votes.

The association can establish another procedure in the by-laws for in-

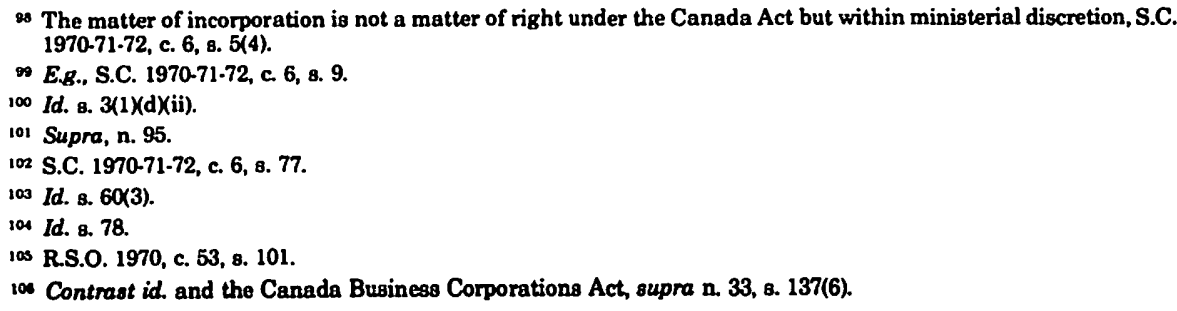


itiating business if it so wishes. The section does not guarantee or entrench the procedure therein stated. However, because of the words "in the absence of other provisions in that behalf in this Act" it seems that where $20 \%$ of the shareholders requisition or call a meeting they shall determine the business to be considered thereat. Section $78(2)$ provides that a requisition shall state "the general nature of the business to be transacted at the meeting." These words would surely be considered "other provisions . . . in this Act" within the meaning of Section 79(3); otherwise the requisitioning power of the members would be meaningless. Therefore $20 \%$ of the members can see to it that certain business is brought before a special general meeting. The $20 \%$ provision is somewhat high when one considers comparable provisions in other corporate legislation. ${ }^{107}$ However, there is no provision in the Act allowing a shareholder or a group of shareholders to submit a proposal to the co-operative for consideration at the next general meeting. The only avenue open to such shareholders is to requisition a special general meeting if support of $20 \%$ of the members is obtained. The absence of a provision enabling the submission of proposals for consideration at annual meetings seems somewhat unreasonable and awkward especially when the power to call a special general meeting exists. If the by-laws are silent on the point a member can raise matters of business if he obtains majority approval, 108 but an alternate procedure contained in the by-laws would clearly preclude him from so doing.

Ultimate authority is given to the Minister to call a meeting in any circumstances on the application of any director, member or delegate. ${ }^{109}$ This roughly corresponds to the right, contained in some corporate legislation, ${ }^{110}$ of shareholders to ask the court to call a meeting. In the Canada Act it is another example of the vast discretionary power given to the Minister.

Also the Canada Act does not state specifically what information circulars, which must accompany notices of meetings, must contain. It leaves this matter to be prescribed by regulation. ${ }^{111}$ Perhaps the Act should contain more specific guidelines such as a requirement that notices of special general meetings contain information as to the purpose of the meeting or that all matters intended to be raised by management at any meeting be stated in the meeting notice. The only requirement presently is that the time and place of the meeting be stated in the notice.112 If proxy voting is allowed ${ }^{113}$ will proxy solicitations be allowed and, if so, what information must such solicitations contain? Presumably these matters are important enough to be contained in the Act itself and not governed by the regulations.

There is no provision in the Canada Act allowing a member to maintain an action in a representative capacity on behalf of the co-operative. Thus the co-operative member who wishes to remedy a wrong done to the corporation is relegated to the elaborate rules set down by common law to govern such matters. ${ }^{114}$ There is no reason why co-operative legislation should not contain provisions to govern such actions.

The Canada Act contains the most elaborate provisions pertaining to

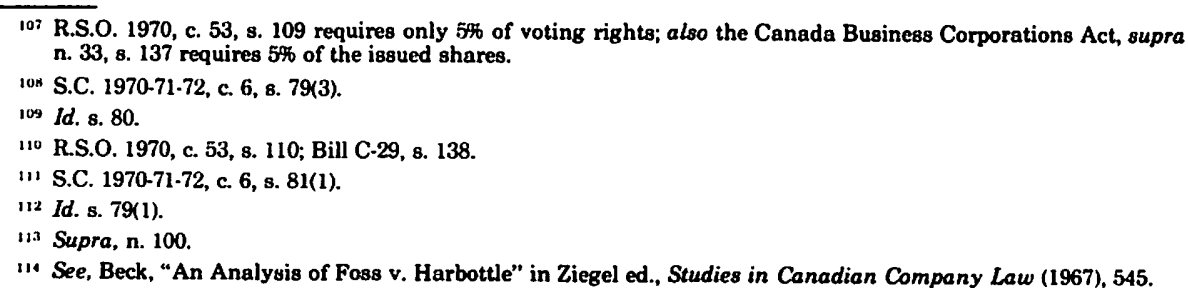


members' rights, although similar provisions are not completely absent in all other co-operative Acts. ${ }^{15}$ But again the law making bodies when considering co-operative legislation could gain from the existing ordinary corporate legislation and incorporate into the co-operative statutes provisions which would clarify and guarantee members' rights in the management and operation of the co-operative association. None of the co-operative Acts contain provisions which deal as well with these important matters as does recent general corporate legislation. ${ }^{116}$

\section{CONCLUSION}

It becomes readily apparent that all Canadian co-operative statutes are seriously deficient in their treatment of management and members. The Canada Co-operative Associations Act, less than five years old, is already out of date-indeed the Canada Act was out of date at the time of its passing. It is hoped that the various legislative bodies will take steps to modernize their respective co-operative legislation in much the same way as some of these same legislative bodies have changed their general corporation statutes. Such change is long overdue. the Ontario BCA. The Committee saw no reason to distinguish between co-operatives and ordinary business corporations in these matters, see the Ontario Report, at 53. 